\title{
Effects of khat use on response to antipsychotic medications in patients with newly diagnosed schizophrenia: a retrospective study
}

Tahir Hakami, ${ }^{1}$ Mahmoud Mahmoud, ${ }^{1}$ Barakat Mohammed ${ }^{2}$ and Maged El-Setouhy ${ }^{1,3}$

${ }^{1}$ The Faculty of Medicine, Jazan University, Jazan, Saudi Arabia (Correspondence to: T. Hakami: hakamit@jazanu.edu.sa). ${ }^{2}$ Al-Amal Psychiatric Hospital, Ministry of Health, Jazan, Saudi Arabia. ${ }^{3}$ The Substance Abuse Research Center (SARC), Jazan University, Jazan, Saudi Arabia

\begin{abstract}
Background: Khat contains the amphetamine-like cathinone, and can trigger onset of schizophrenia and exacerbate pre-existing psychosis. However, it remains unknown whether the use of khat complicates the outcome of schizophrenia treatment.
\end{abstract}

Aims: We tested the hypothesis that patients with schizophrenia who are using khat will fail to respond to standard antipsychotic treatment.

Methods: We retrospectively studied a consecutive series of patients who presented to an adult psychiatric clinic in Al-Amal Psychiatric Hospital in Jazan, Saudi Arabia, between January 1, 2013 and December 31, 2016. Patients with newly diagnosed schizophrenia on antipsychotic monotherapy $(n=1007,817$ men) were included and categorized into khat and non-khat users. A khat chewing index was developed to further categorize low, mild, moderate and heavy khat users. Antipsychotic medications were reviewed to determine their potential and the cause of substitution in association with khat use.

Results: There were 483 (48\%) khat users. Olanzapine, haloperidol and aripiprazole were the most frequently used drugs (46.3\%, 15.6\% and 10\%, respectively). The retention rate of the initial drug differed between the khat users and nonusers (53.8\% and $78.4 \%$, respectively). The proportion of moderate and heavy users ( $55 \%$ and $49 \%$, respectively) who changed their initial drug was greater than that of low and mild users (35.6\% and $44.7 \%$, respectively). Lack of drug efficacy was the most appealing reason for switching the initial drug among moderate (51.7\%) and heavy khat users (48.4\%).

Conclusions: Khat use hinders an individual's response to initial antipsychotic drug treatment for schizophrenia. Further studies are warranted to investigate the treatment decisions for this group of patients.

Keywords: antipsychotics, drug response, khat, schizophrenia, treatment outcome

Citation: Hakami T; Mahmoud M; Mohammed B; El-Setouhy M. Effects of khat use on response to antipsychotic medications in patients with newly diagnosed schizophrenia: a retrospective study. East Mediterr Health J. 2021;27(4):353-360. https://doi.org/10.26719/emhj.21.003

Received: 09/12/19; accepted: 30/04/20

Copyright (c) World Health Organization (WHO) 2021. Open Access. Some rights reserved. This work is available under the CC BY-NC-SA 3.o IGO license (https://creativecommons.org/licenses/by-nc-sa/3.o/igo)

\section{Introduction}

Khat is a commonly used drug in the Eastern Mediterranean Region, which is becoming more prevalent in some countries, including Saudi Arabia (1). In Jazan, which lies in Southwest Saudi Arabia, khat use has been a traditional practice and the current pattern of use is becoming more excessive (2). Khat is consumed by chewing, which continuously produces pharmacokinetic properties $(3,4)$. The fresh leaves and twigs of the khat shrub contain high concentrations of cathinone, an amphetamine analogue that produces euphoric effects $(3,4)$. The other desired effects reported by khat users include increased energy, empathy, openness, and increased libido $(5,6)$. Although limited use may not be accompanied by serious consequences, prolonged exposure can lead to dependence, psychosis and mood disturbances (7-10). The World Health Organization (WHO) has stated that khat causes psychological but not physical dependence among moderate users who consume the drug on a daily basis (11).

Schizophrenia is a complex neurodevelopmental disorder with high heritability (12). Epidemiological studies from the United States of America, Europe, and Australia have consistently demonstrated that half of patients with a first episode of psychosis have co-occurring substance use disorders (in particular, alcohol, cannabis and stimulants), which is at least 3 times higher than that in the general population (13-15). Co-occurrence may result in more psychotic symptoms (hyperactivity, mood liability, impulsivity, hostility and uncooperativeness), depressive symptoms, and greater perceived stigma (7-10). By contrast, only a few studies have shown that khat has a particular propensity to induce or aggravate psychiatric symptoms in countries where the chewing of khat leaves is common $(8,16,17)$. Little is known about the association between khat use and response to antipsychotic treatment in schizophrenia patients. Importantly, clinicians in our region have the impression that khat use has a higher propensity to induce or aggravate psychiatric symptoms and complicate the outcome of schizophrenia treatment in some patients.

This clinical observation was one of the primary motivations to initiate this study. We retrospectively studied a consecutive series of patients who presented over a 4-year period to an adult psychiatric clinic for assessment with a potential first episode of 
schizophrenia. We included all patients with newly diagnosed schizophrenia on antipsychotic monotherapy. The antipsychotic medications were reviewed to determine their potential and the cause of substitution in association with khat use. We aimed to test the hypothesis that patients with newly diagnosed schizophrenia who are classified as khat users fail to respond to standard antipsychotic monotherapy. Failure was defined as the need to change the initial antipsychotic drug due to lack of efficacy in controlling the symptoms of schizophrenia and/or intolerable adverse effects.

\section{Methods}

\section{Study design}

We retrospectively assessed a consecutive series of patients with newly diagnosed schizophrenia who attended an adult psychiatric clinic in Al-Amal Psychiatric Hospital in Jazan, Saudi Arabia, between January 1, 2013 and December 31, 2016. The study hospital is the only government mental health facility in the region.

\section{Patients}

We included all adults with newly diagnosed schizophrenia on antipsychotic monotherapy. The term newly diagnosed was defined as having no previous diagnosis of schizophrenia and no history of antipsychotic medication 12 months before their first presentation to the adult psychiatric clinic. Patients' data were collected from the Al-Amal Psychiatric Hospital database. The records were assessed thoroughly by 3 psychiatrists, and the following data were entered on a pre-prepared electronic data collection sheet on the survey monkey database: sex, age, detailed description of symptoms, clinical presentation, investigations, antipsychotic medication, drug combination with other central nervous system (CNS) stimulants or depressants, khat chewing behaviour (duration, frequency and amount), and screening tests for other CNS stimulants. We excluded patients with a history of substance abuse including amphetamines, alcohol and cannabis, and history of medication that could affect dopaminergic neurotransmission within 3 months before the first presentation.

\section{Adult psychiatric clinic: routine investigation and diagnosis}

Each patient was assessed thoroughly by a consultant psychiatrist. This included a detailed description of events of interest as well as associated symptoms. Screening tests to detect the presence of amphetamines or cannabinoids were routinely requested. Since chewing khat is more prevalent in this region than in other areas of the country, questioning patients regarding khat use is part of the daily practice in the clinics, and precise information is always obtained. Diagnosis of schizophrenia was established by a consultant psychiatrist according to International Classification of Diseases, 10th Revision.

\section{Khat chewing index}

A simple index was developed to measure the degree of khat use according to the data available. The index was also used us to categorize khat users into groups. The idea was based on the smoking severity index with some modifications to measure khat use.

Khat chewing index = amount of khat usually used/ session $\times$ number of days usually using khat/week during the last year $\times$ number of years of using khat

The amount of khat used was calculated and expressed in piles $(\sim 1 \mathrm{~kg})$. We did not multiply the number of days per week by 48 weeks, as the same number was used to calculate the amount of khat consumed by all users, and doing so would have increased the result for no reason. Hence, all khat users were categorized into quartile bases in order to develop the following 5 categories: 1- non-khat users; 2- low users, comprising khat users with an index $<25 \%$; 3 - mild users, comprising khat users with an index of $25-50 \% ; 4$ - moderate users, comprising khat users with an index of 50-75; and 5- heavy users, comprising khat users with an index $>75 \%$.

\section{Statistical analysis}

Descriptive analyses were performed using SPSS for Mac version 23. For analysis of age differences in terms of the proportion of patients whose initial antipsychotic treatment was substituted, both khat users and nonusers were categorized into three age groups (18-24, 25-44 and 45-64 years). The proportion of patients whose initial antipsychotic treatment was substituted was measured in each age group. Categorical comparisons were carried out using the $\chi^{2}$ test. The level of significance was set as $P<0.05$.

\section{Ethical approval}

The study was approved by the Jazan Health Human Research Ethics Committee (HREC No. 1437-SCBRE-03). Patient confidentiality was maintained by coding patients' files without disclosure of any private information.

\section{Results}

\section{Patient characteristics}

We included 1007 patients with newly diagnosed schizophrenia on antipsychotic monotherapy [mean (standard deviation) age: 33.6 (9.7) years, range: $18-77$ years] (Table 1). Of those patients, 817 (81.1\%) were men and 492 (48.9\%) were khat users. Approximately $56 \%$ of patients achieved below secondary educational level, while $57.5 \%$ were unemployed. Of the 1007 patients, $193(19 \%)$ were lost to follow-up after their first presentation. There was no significant difference between the proportion of khat users and non-khat users lost to follow-up after their first presentation (104/483, $21.5 \%$ vs $89 / 524,17 \%$, respectively).

\section{Antipsychotic drugs}

Atypical antipsychotics were more preferred than the typical agents (Table 2). The most commonly used atypi- 


\begin{tabular}{|c|c|c|c|}
\hline Demographic characteristics & Khat users & Non-khat users & Total \\
\hline \multicolumn{4}{|l|}{ Patients, $\boldsymbol{n}(\%)$} \\
\hline Low & $118(11.7)$ & $524(52.0)$ & 1007 \\
\hline Mild & $123(12.2)$ & - & - \\
\hline Moderate & $120(11.9)$ & - & - \\
\hline Heavy & $122(12.1)$ & - & - \\
\hline Total & $483(48.0)$ & - & - \\
\hline Age, mean (SD) years & $33.3(8.6)$ & $33.9(10.6)$ & $33.6(9.7)$ \\
\hline \multicolumn{4}{|l|}{$\operatorname{Sex}, n(\%)$} \\
\hline Male & 489 (59.9) & $328(40.1)$ & $817(81.1)$ \\
\hline Female & $3(1.6)$ & $187(98.4)$ & $190(18.9)$ \\
\hline \multicolumn{4}{|l|}{ Education, $n(\%) a$} \\
\hline Less than high school & $232(52.6)$ & $209(47.4)$ & $441(43.7)$ \\
\hline High school & $186(52.8)$ & $166(47.20$ & $352(35.0)$ \\
\hline Bachelor degree & $35(47.3)$ & $39(52.7)$ & $74(7.3)$ \\
\hline Graduate degree & $2(40.0)$ & $3(60.0)$ & $5(0.5)$ \\
\hline Not educated & $35(28.2)$ & $89(71.8)$ & $124(12.3)$ \\
\hline \multicolumn{4}{|l|}{ Employment, $\boldsymbol{n}(\%) \boldsymbol{b}$} \\
\hline Employed & $188(57.5)$ & $139(42.5)$ & $327(32.5)$ \\
\hline Unemployed & $264(45.7)$ & $314(54.3)$ & $578(57.5)$ \\
\hline Retired & $32(62.7)$ & $19(37.3)$ & $51(5.1)$ \\
\hline Student & $6(16.7)$ & $30(83.3)$ & $36(3.6)$ \\
\hline Housewife & $\mathrm{o}(0)$ & 13 (100.0) & $13(1.3)$ \\
\hline
\end{tabular}

${ }^{a_{11}}$ cases missed (1.1\%); ${ }^{b} 2$ cases missed $(0.2 \%)$.

cal antipsychotic drugs were olanzapine (46.3\%), followed by aripiprazole (10.0\%), and risperidone (9.3\%). Haloperidol was the only typical antipsychotic used (15.6\%).

\section{Effects of khat use on antipsychotic drugs}

Table 3 shows the effect of khat use on the retention rate of the initial antipsychotic drug. The difference in the initial drug retention rate between khat users and nonusers was significant (53.8\% and $78.4 \%$ respectively, $P<0.001$ ). The proportion of moderate and heavy khat users who changed their initial drug was significantly higher than that of low and mild khat users (55\% and $49.2 \%$ vs. $35.6 \%$ and $44.7 \%$ respectively, $P<0.001$ ). There was no significant sex difference between khat users and nonusers in terms of the proportion of patients whose initial antipsychotic treatment was substituted.

Table 4 shows the effect of khat use on substitution of the initial antipsychotic drug according to age group. Khat users aged 25-44 and 45-64 years had a significantly greater rate of drug substitution compared to those in the nonuser group (70.4\% and $69.2 \%$ vs. $29.6 \%$ and $30.8 \%$ respectively, $\mathrm{P}<0.005)$.

\section{Reasons for initial antipsychotic drug substitution}

Table 5 indicates that lack of drug efficacy was the most common reason for switching initial antipsychotic drug in $51.7 \%$ and $48.4 \%$ of moderate and heavy khat users, re- spectively. Drug adverse effects and noncompliance, although common in those treated with antipsychotics, led to changes in initial drug treatment in a few cases only.

\section{Discussion}

This study assessed drug treatment outcomes in a clinically important, but understudied, group of patients with schizophrenia who were khat users and in an area where most people use khat as a tradition. Almost half of schizophrenia patients were khat users. Substitution of initial drug was greater in khat users than nonusers, and in the moderate and heavy khat users than low and mild users. Lack of drug efficacy was the main reason for switching the initial antipsychotic drug. These findings indicate that khat use hinders the response to initial antipsychotic drug treatment for schizophrenia.

The management of schizophrenia has become an enormous challenge and opportunity, particularly in patients with a lifetime history of use of substances like khat (Catha edulis). The evaluation and treatment decisions that are implemented in this situation can have an important impact on the subsequent course and outcome of schizophrenia. This study is believed to be the first to address the interaction between antipsychotic drug and khat use in patients with newly diagnosed schizophrenia. The findings shed light on the many questions around appropriate treatment strategies and 


\begin{tabular}{|c|c|c|}
\hline Drugs & $\begin{array}{l}\text { Patients, n } \\
\text { (\%) }\end{array}$ & $\begin{array}{l}\text { Maintenance } \\
\text { dose, median } \\
\text { (range) }\end{array}$ \\
\hline Amisulpride & $10(1.0)$ & $400(200-800)$ \\
\hline Aripiprazole & $102(10.1)$ & $15(5-30)$ \\
\hline Clozapine & $2(0.2)$ & $325(250-400)$ \\
\hline Haloperidol & $157(15.6)$ & $10(2-15)$ \\
\hline $\begin{array}{l}\text { Haloperidol (+ long-acting } \\
\text { haloperidol) }\end{array}$ & $7(0.7)$ & $10(5-10])$ \\
\hline Olanzapine & $466(46.3)$ & $10(5-20)$ \\
\hline Paliperidone & $74(7.3)$ & $6(2-9)$ \\
\hline Quetiapine & $80(7.9)$ & $300(100-800)$ \\
\hline Risperidone & $94(9.3)$ & $4(1-8)$ \\
\hline $\begin{array}{l}\text { Risperidone (+ long acting } \\
\text { risperidone) }\end{array}$ & $6(0.6)$ & $5(4-8)$ \\
\hline Trifluoperazine & $9(0.9)$ & $1(1-1)$ \\
\hline
\end{tabular}

clinical recommendations for this important group of patients.

It has been suggested that excessive limbic dopaminergic activity plays a role in schizophrenia (dopamine hypothesis), with much emphasis on this role through the fact that the antipsychotic effect of typical drugs, such as haloperidol, is due to their blockade of dopamine $\left(D_{2}\right)$ receptors (18). However, the dopamine hypothesis does not fully explain all aspects of schizophrenia. Diminished cortical or hippocampal dopaminergic activity has been found to underlie the negative symptoms of schizophrenia (e.g., emotional blunting, social withdrawal and lack of motivation). The atypical antipsychotic agents, which are potent serotonin $\left(5 \mathrm{HT}_{2 \mathrm{~A}}\right)$ receptor antagonists with less effect on $\mathrm{D}_{2}$ receptors, have also been developed and proved to be more effective than the typical antipsychotic agents in treating negative symptoms of schizophrenia. The adverse effects, mainly extrapyramidal dysfunction, of the aforementioned drugs are fewer compared with those caused by typical antipsychotics (19). This finding

\begin{tabular}{|c|c|c|c|}
\hline \multicolumn{4}{|c|}{$\begin{array}{l}\text { Table } 3 \text { Frequency of substitution of initial (first-line) } \\
\text { antipsychotic drug prescribed to patients with newly } \\
\text { diagnosed schizophrenia in association with khat use }\end{array}$} \\
\hline $\begin{array}{l}\text { Khat chewing } \\
\text { index }\end{array}$ & $\begin{array}{l}\text { Initial drug not } \\
\text { substituted, } \mathbf{n} \\
(\%)\end{array}$ & $\begin{array}{l}\text { Initial drug } \\
\text { substituted, } \\
\text { n (\%) }\end{array}$ & Total \\
\hline Nonusers & $411(78.4)$ & $113(21.6)$ & 524 \\
\hline Low users & $76(64.4)$ & $42(35.6)$ & 118 \\
\hline Mild users* & $68(55.3)$ & $55(44.7)$ & 123 \\
\hline Moderate users* & $54(45.0)$ & 66 (55.0) & 120 \\
\hline Heavy users* & $62(50.8)$ & $60(49.2)$ & 122 \\
\hline Total & $671(66.6)$ & $336(34.4)$ & 1007 \\
\hline
\end{tabular}

was also observed among patients using medication for schizophrenia at Jazan Psychiatric Hospital. Despite the efficacy of the antipsychotics, only $50 \%$ of the population responded. Poor response is associated with relapse, exacerbation, and premature discontinuation of treatment. Patients who fail to respond to treatment have a higher risk of hospitalization, and this could result in an increase in treatment cost $(16,20)$.

Another cause of failure of treating schizophrenia symptoms is comorbid substance abuse, which commonly leads to dual diagnosis. Substance abuse, particularly amphetamines, is responsible for $40 \%$ of cases of psychosis (21). The dual diagnosis of schizophrenia and substance abuse comprises $50 \%$ of all schizophrenia patients (13), which is consistent with the results of the present study. It is often challenging to determine whether a patient has primary schizophrenia or substance abuse. Nevertheless, careful clinical interview and substance abuse screening may result in a rapid and accurate diagnosis. In the present study, khat (which is pharmacologically equivalent to amphetamine, but with lower potency) exacerbated schizophrenia symptoms, resulting in treatment failure $(5,6)$. The treatment failure was more prevalent in the moderate and heavy khat users when we applied the khat chewing index, which determined the potential of drug substitution in association with the degree of khat use.

Much of the available information regarding the chemical constituents in khat arose from studies funded by WHO (3). Phenylalkylamines, which bear structural resemblance to the neurotransmitters dopamine and noradrenaline, are believed to be responsible for the psychostimulant nature of khat (22). These phenylalkylamines comprise cathinone and 2 diastereoisomers of cathine (norpseudoephedrine and norephedrine). Users of khat traditionally chew the youngest shoots and leaves, which contain the highest concentrations of cathinone (3). Cathinone appears to increase dopaminergic neurotransmission in a similar manner to amphetamine, by triggering presynaptic dopamine release and by inhibiting the reuptake of dopamine (23-25). Cathinone releases serotonin into the CNS (23). Therefore, khat can produce dose-dependent psychotic symptoms and worsen pre-existing psychosis. The risk-increasing effects have not yet been fully explained.

It is well established that the psychotic exacerbation of khat is dose dependent (1). The khat chewing habit varies from mild to excessive use among the Jazan population. Therefore, the khat chewing index was developed to determine the degree of khat use among individuals with schizophrenia. A total of 1007 patients aged $18-77$ years were included in the present study. Data were collected to evaluate the changes in initial antipsychotic medication in relation to the 5 categories of khat use. A significant difference was observed in medication change between the groups. The results indicated a significant difference in medication change among patients with low, mild and heavy khat use compared with non-khat users. This suggests that the physicians usually administer the 


$\begin{aligned} & \text { Table 4 Comparison between khat users and nonusers in } \\
& \text { terms of proportion of patients whose initial antipsychotic } \\
& \text { treatment was substituted, according to age group }\end{aligned}$
\begin{tabular}{|cccc}
\hline Age group (yr) & $\begin{array}{c}\text { Number (\%) of patients whose } \\
\text { initial antipsychotic treatment } \\
\text { was substituted }\end{array}$ & Total \\
& Khat users & Nonusers & \\
\hline $18-24$ & $29(48.3)$ & $31(51.7)$ & 60 \\
$25-44$ & $176(70.4)$ & $74(29.6)$ & 250 \\
$45-64$ & $18(69.2)$ & $8(30.8)$ & 26 \\
Total & 223 & 113 & 336 \\
\hline
\end{tabular}

maximum dose of antipsychotic drugs during the initial treatment, as observed in the present study.

Lack of drug efficiency was the most common reason for switching initial antipsychotic drugs, particularly among mild, moderate and heavy khat users. It significantly exceeded the development of intolerable adverse effects and noncompliance, which are more common in individuals with schizophrenia on antipsychotic drugs. This is despite the fact that, in the present study, antipsychotics were given at their maximum therapeutic doses. Failure to control schizophrenia symptoms prompts physicians to change the initial antipsychotic drug. This can be explained by the dual diagnosis of schizophrenia and khat use since khat intensifies the state of psychosis. This situation may require either increasing the dose or shifting to more efficient antipsychotics. To date, no pharmacological studies have reported the treatment decisions in this important group of patients. Until then, khat abstinence would be the mainstay of treatment, in addition to antipsychotic agents, psychological therapy, social support, and rehabilitation $(11,17,26)$.

While this study had a number of strengths, including the number of individuals studied, it was also limited by its retrospective nature, which we attempted to minimize. In particular, the psychiatric assessment of symptoms, the causative relationship between khat use and antipsychotic efficacy, and the reason for antipsychotic switching, which were revisited and confirmed by the treating psychiatrists. The mean age of patients suggests that even if the diagnosis had been recent, the onset of signs and symptoms could have been earlier. This finding could be explained by the fact that mental health conditions in Saudi Arabia are still considered to be a stigma. The Saudi National Health and Stress Survey (unpublished technical report, 2019) showed that 34\% of Saudis meet the criteria for a mental health condition in their life, and only 5\% of Saudis seek treatment for their mental health condition in a given year.

The study was limited by the self-reported use of khat, which meant that there was greater potential for information bias arising from the patients. However, taking into account that khat use is a traditional practice in the region, investigating the degree of khat use among patients is part of the daily practice in clinics, and precise information is always obtained. Another potential limitation was the lack of data on the titration pattern of drug dose. This could be explained by the fact that treating physicians usually start with the maximum well-tolerated dose of the antipsychotic drug in khat users. Moreover, we cannot exclude the fact that other confounding factors (e.g., other substance abuse, comorbidities, and adherence to treatment) may have contributed to the necessary change in initial antipsychotic medication (treatment failure). Hence, a prospective study is warranted to determine other confounding factors.

\section{Conclusion}

Khat is popular among schizophrenia patients, which makes them vulnerable to drug treatment failure. As we anticipated, antipsychotics were initiated using the maximum therapeutic dose in areas (such as Jazan) where psychostimulant drugs are used. This study opens the door for prospective studies to try and understand the phenomenon of khat use in schizophrenia and encourage the authorities to adopt more aggressive measures to avoid khat use.

\begin{tabular}{|c|c|c|c|c|c|c|}
\hline Khat chewing index, $\mathbf{n}(\%)$ & $\begin{array}{l}\text { Adverse } \\
\text { effects }\end{array}$ & $\begin{array}{l}\text { Lack of } \\
\text { efficacy }\end{array}$ & $\begin{array}{c}\text { Treatment } \\
\text { noncompliance }\end{array}$ & $\begin{array}{l}\text { Other } \\
\text { reasons }\end{array}$ & Not substituted & Total \\
\hline Nonusers & $18(3.4)$ & $42(8.0)$ & $2(0.4)$ & $51(9.7)$ & $411(78.4)$ & 524 \\
\hline Low users & $0(0.0)$ & $35(29.7)$ & $2(1.7)$ & $5(4.2)$ & $76(64.4)$ & 118 \\
\hline Mild users* & $3(2.4)$ & $50(40.7)$ & $\mathrm{o}(0.0)$ & $2(1.6)$ & $68(55.3)$ & 123 \\
\hline Moderate users* & $1(0.8)$ & $62(51.7)$ & $\mathrm{o}(0.0)$ & $3(2.5)$ & $54(45.0)$ & 120 \\
\hline Heavy users* & $0(0.0)$ & $59(48.4)$ & $\mathrm{o}(0.0)$ & $1(0.8)$ & $62(50.8)$ & 122 \\
\hline Total & $22(2.2)$ & $248(24.6)$ & $4(0.4)$ & $62(6.2)$ & $671(66.6)$ & 1007 \\
\hline
\end{tabular}




\section{Acknowledgement}

The authors acknowledge the contributions of Drs Ahmed El-Tantawy and Mahmoud Osman, Al-Amal Psychiatric Hospital, Jazan, Saudi Arabia, for their assistance with data acquisition.

Funding: The study was funded by the Substance Abuse Research Center (SARC), through the Deanship of Scientific Research, Jazan University, Jazan, Saudi Arabia. SARC had no role in the study design, data acquisition, analysis, and interpretation, nor in the drafting of this manuscript.

Competing interests: None declared.

\section{Effets de la consommation de khat sur la réponse aux médicaments antipsychotiques chez les patients atteints de schizophrénie récemment diagnostiquée : étude rétrospective}

\section{Résumé}

Contexte: Le khat contient de la cathinone de type amphétamine, qui peut déclencher une schizophrénie et exacerber une psychose préexistante. Cependant, on ne sait toujours pas si l'utilisation du khat complique le résultat du traitement de la schizophrénie.

Objectifs: Notre objectif était de tester l'hypothèse selon laquelle les patients atteints de schizophrénie qui consomment du khat ne répondront pas au traitement antipsychotique standard.

Méthodes: Nous avons procédé à une étude rétrospective sur une série de patients qui se sont présentés dans une clinique psychiatrique pour adultes à l'hôpital psychiatrique Al-Amal de Jazan, en Arabie saoudite, entre le $1^{\text {er }}$ janvier 2013 et le 31 décembre 2016. Les patients souffrant de schizophrénie nouvellement diagnostiquée et suivant une monothérapie antipsychotique ( $n=1007,817$ hommes) ont été inclus dans l'étude et classés en deux catégories: les consommateurs et les non consommateurs de khat. Un indice de consommation du khat a été mis au point pour mieux catégoriser les personnes ayant une consommation faible, légère, modérée et importante. Les médicaments antipsychotiques ont été examinés afin de déterminer leur potentiel et la cause de la substitution en association avec la consommation de khat.

Résultats: Il y avait 483 consommateurs de khat (48\%). L'olanzapine, l'halopéridol et l'aripiprazole étaient les médicaments les plus fréquemment utilisés $(46,3 \%, 15,6 \%$ et $10 \%$, respectivement). Le taux de rétention du médicament initial différait entre les consommateurs et les non consommateurs de khat $(53,8 \%$ et $78,4 \%$, respectivement). La proportion de personnes ayant une consommation modérée et importante (55\% et $49 \%$, respectivement) qui ont changé leur médicament initial était supérieure à celle des personnes ayant une consommation faible et légère $(35,6 \%$ et $44,7 \%$, respectivement). Le manque d'efficacité du médicament a été la raison la plus populaire pour changer le médicament initial chez les personnes ayant une consommation modérée $(51,7 \%)$ et importante $(48,4 \%)$.

Conclusions : La consommation de khat entrave la réponse d'un individu au traitement antipsychotique initial de la schizophrénie. Des études supplémentaires sont nécessaires pour examiner les décisions thérapeutiques pour ce groupe de patients.

$$
\begin{aligned}
& \text { آثار استخدام القاث على استجابة مرضى الفصام المشخصين حديثًا للأدوية المضادة للذهان: دراسة استرجاعية } \\
& \text { طاهر حكمي، محمود محمود، بركات محمد، ماجد السطوحي } \\
& \text { الخالاصة }
\end{aligned}
$$

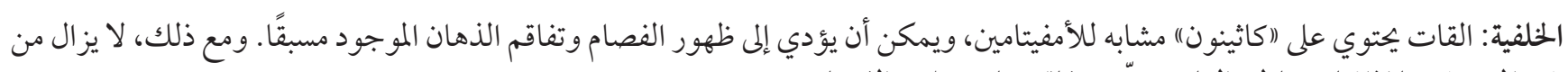

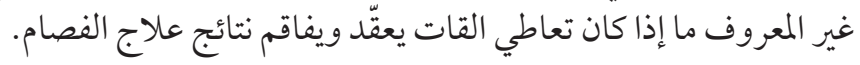

$$
\begin{aligned}
& \text { الأهداف: هدفت هذه الدراسة إلى اختبار فرضية أن مرضى الفصام الذين يستخدمون القات سيفشلون في الاستجابة للعلاج المعياري المضاد } \\
& \text { للنهان. }
\end{aligned}
$$

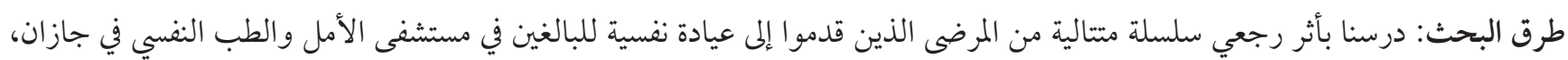

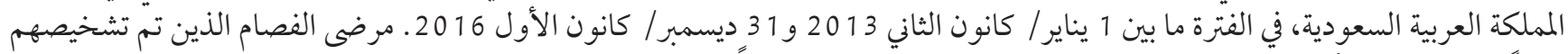

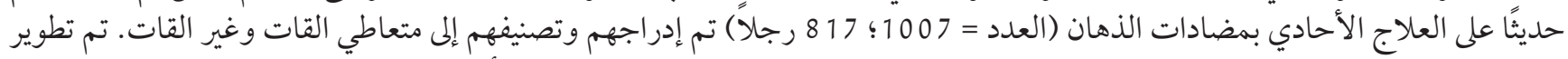

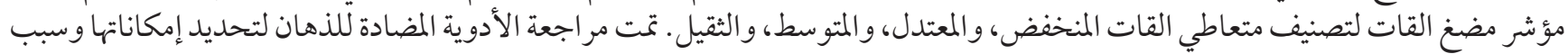

$$
\begin{aligned}
& \text { الاستبدال بالاشتراك مع استخدام الكّات. }
\end{aligned}
$$




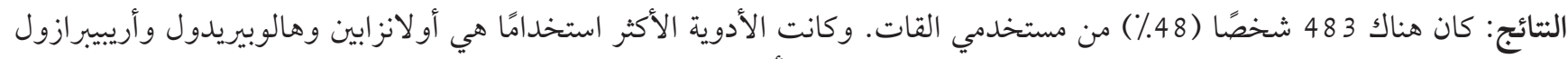

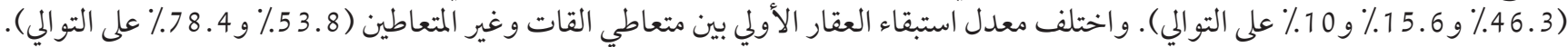

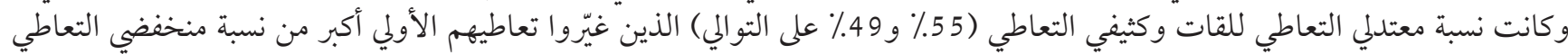

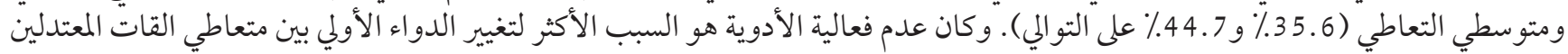

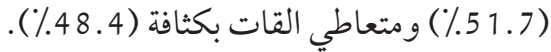

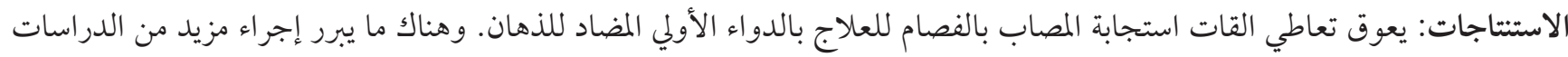

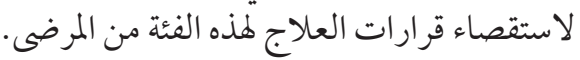

\section{References}

1. Odenwald M, al'Absi M. Khat use and related addiction, mental health and physical disorders: the need to address a growing risk. East Mediterr Health J. 2017 Mar;23(3):236-44. https://doi.org/10.26719/2017.23.3.236. PMID:28493272

2. Al-Sanosy RM. Pattern of khat abuse and academic performance among secondary school and college students in Jazan Region, Kingdom of Saudi Arabia (KSA). J Family Community Med. 2009 Sep;16(3):89-95. PMID:23012198

3. Nichols T, Khondkar P, Gibbons S. The psychostimulant drug khat (Catha edulis): a mini-review. Phytochem Lett. 2015 Sep;13:127-33. https://doi.org/10.1016/j.phytol.2015.05.016

4. Al-Hebshi NN, Skaug N. Khat (Catha edulis) - an updated review. Addict Biol. 2005 Dec;10(4):299-307. https://doi. org/10.1080/13556210500353020 PMID:16318950

5. Valente MJ, Guedes de Pinho P, de Lourdes Bastos M, Carvalho F, Carvalho M. Khat and synthetic cathinones: a review. Arch Toxicol. 2014 Jan;88(1):15-45. https://doi.org/10.1007/s00204-013-1163-9 PMID:24317389

6. Engidawork E. Pharmacological and toxicological effects of Catha edulis F. (Khat). Phytother Res. 2017 Jul;31(7):1019-28. https:// doi.org/10.1002/ptr.5832 PMID:28557133

7. Adorjan K, Odenwald M, Widmann M, Tesfaye M, Tessema F, Toennes S, et al. Khat use and occurrence of psychotic symptoms in the general male population in Southwestern Ethiopia: evidence for sensitization by traumatic experiences. World Psychiatry. 2017 Oct;16(3):323. http://doi.org/10.1002/wps.20470 PMID:28941092

8. Odenwald M, Neuner F, Schauer M, Elbert T, Catani C, Lingenfelder B, et al. Khat use as risk factor for psychotic disorders: a cross-sectional and case-control study in Somalia. BMC Med. 2005 Feb 12;3:5. https://doi.org/10.1186/1741-7015-3-5 PMID:15707502

9. Ismail AA, El Sanosy RM, Rohlman DS, El-Setouhy M. Neuropsychological functioning among chronic khat users in Jazan region, Saudi Arabia. Subst Abus. 2014;35(3):235-44. https://doi.org/10.1080/08897077.2013.832469 PMID:24965057

10. El-Setouhy M, Alsanosy RM, Alsharqi A, Ismail AA. Khat dependency and psychophysical symptoms among chewers in Jazan Region, Kingdom of Saudi Arabia. Biomed Res Int. 2016;2016:2642506. https://doi.org/10.1155/2016/2642506 PMID:27022605

11. WHO Expert Committee on Drug Dependence. Thirty-fourth report. Geneva: World Health Organization; 2006 (WHO Technical Report Series 942; https://apps.who.int/iris/bitstream/handle/10665/43608/9789241209427_eng.pdf;jsessionid=7FD27D9BE40AADC7AB8C223CoAoBBCD7? sequence=1, accessed 4 December 2020).

12. Doherty JL, O’Donovan MC, Owen MJ. Recent genomic advances in schizophrenia. Clin Genet. 2012 Feb;81(2):103-9. http://doi. org/10.1111/j.1399-0004.2011.01773.x PMID:21895634

13. Brunette MF, Mueser KT, Babbin S, Meyer-Kalos P, Rosenheck R, Correll CU, et al. Demographic and clinical correlates of substance use disorders in first episode psychosis. Schizophr Res. 2018 Apr;194:4-12. http://doi.org/10.1016/j.schres.2017.06.039 PMID:28697856

14. Sara GE, Burgess PM, Malhi GS, Whiteford HA, Hall WC. Stimulant and other substance use disorders in schizophrenia: prevalence, correlates and impacts in a population sample. Aust N Z J Psychiatry. 2014 Nov;48(11):1036-47. http://doi. org/10.1177/0004867414533838 PMID:24819935

15. Van Mastrigt S, Addington J, Addington D. Substance misuse at presentation to an early psychosis program. Soc Psychiatry Psychiatr Epidemiol. 2004 Jan;39(1):69-72. http://doi.org/10.1007/s00127-004-0713-o PMID:15022049

16. Bimerew MS, Sonn FC, Kortenbout WP. Substance abuse and the risk of readmission of people with schizophrenia at Amanuel Psychiatric Hospital, Ethiopia. Curationis. 2007 Jun;30(2):74-81. https://doi.org/10.4102/curationis.v30i2.1078 PMID:17703825

17. Odenwald M, Lingenfelder B, Peschel W, Haibe FA, Warsame AM, Omer A, et al. A pilot study on community-based outpatient treatment for patients with chronic psychotic disorders in Somalia: change in symptoms, functioning and co-morbid khat use. Int J Ment Health Syst. 2012;6:8. https://doi.org/10.1186/1752-4458-6-8

18. Davis KL, Kahn RS, Ko G, Davidson M. Dopamine in schizophrenia: a review and reconceptualization. Am J Psychiatry. 1991 Nov;148(11):1474-86. http://doi.org/10.1176/ajp.148.11.1474 PMID:1681750

19. de Araujo AN, de Sena EP, de Oliveira IR, Juruena MF. Antipsychotic agents: efficacy and safety in schizophrenia. Drug Healthc Patient Saf. 2012;4:173-80. http://doi.org/10.2147/DHPS.S37429 PMID:23236256

20. Lieberman JA, Stroup TS, McEvoy JP, Swartz MS, Rosenheck RA, Perkins DO, et al. Effectiveness of antipsychotic drugs in patients with chronic schizophrenia. N Engl J Med. 2005 Sep 22;353(12):1209-23. https://doi.org/10.1056/NEJMoa051688 PMID:16172203 
21. Hartel-Petri R, Krampe-Scheidler A, Braunwarth WD, Havemann-Reinecke U, Jeschke P, Looser W, et al. Evidence-based guidelines for the pharmacologic management of methamphetamine dependence, relapse prevention, chronic methamphetamine-related, and comorbid psychiatric disorders in post-acute settings. Pharmacopsychiatry. 2017 May;50(3):96-104. http://doi. org/10.1055/s-0043-105500 PMID:28445899

22. Wabe NT. Chemistry, pharmacology, and toxicology of khat (catha edulis forsk): a review. Addict Health. 2011;3(3-4):137-49. PMID:24494129

23. Feyissa AM, Kelly JP. A review of the neuropharmacological properties of khat. Prog Neuropsychopharmacol Biol Psychiatry. 2008 Jul 1;32(5):1147-66. http://doi.org/10.1016/j.pnpbp.2007.12.033 PMID:18561890

24. Hoffman R, Al'Absi M. Khat use and neurobehavioral functions: suggestions for future studies. J Ethnopharmacol. 2010 Dec 1;132(3):554-63. http://doi.org/10.1016/j.jep.2010.05.033 PMID:20553832

25. Kalix P, Braenden O. Pharmacological aspects of the chewing of khat leaves. Pharmacol Rev. 1985 Jun;37(2):149-64. PMID:2864707

26. Alsanusy R, El-Setouhy M. Why would khat chewers quit? An in-depth, qualitative study on Saudi Khat quitters. Subst Abus. 2013;34(4):389-95. http://doi.org/10.1080/08897077.2013.783526 PMID:24159910 